DOI: $10.26693 / \mathrm{jmbs} 04.05 .345$

UDC 616-001.3-092.9-02:613.84

Tkachenko V. M. ${ }^{1}$, Komisova T. E. ${ }^{2}$

\title{
LONG-TERM EFFECTS OF PARENTS' PASSIVE SMOKING ON THE MORPHOFUNCTIONAL STATUS OF ADRENAL GLANDS AND THYMUS IN THEIR DESCENDANTS
}

\author{
${ }^{1}$ Kharkiv Specialized School of I-III degrees № 134, Ukraine \\ ${ }^{2}$ H. S. Skovoroda Kharkiv National Pedagogical University, Ukraine \\ tatyanakomisova@gmail.com; annetka1999@ukr.net
}

The purpose of our research was to study the morphofunctional status of the adrenal glands and thymus in the descendants with a mechanical wound to determine the long-term consequences effects of their parents' passive smoking on resistance and reactivity.

Material and methods. The study was carried out on 73 rats (25 females and 10 males aged 3 months; 38 descendant females at the age of 2 months) belonging to the Vistar line. The animals were kept under normal vivarium conditions under natural light, with a common diet. The use of water was free.

Results and discussion. The study showed that changes in the morphofunctional status of the adrenal glands and thymus in the descendants of rats born from parents exposed to passive tobacco smoking are manifested depending on fumigation of only the father or father and mother, as well as the period of the skin cut made. Reduction of the spongiocytes total number in the descendant sacrificed in $24 \mathrm{~h}$ and $48 \mathrm{~h}$ after mechanical wounding, whose father was subjected to passive tobacco smoking using the "Priluki" light cigarettes (groups 2, 5), amounted by $27 \%$ and $25 \%$, respectively. Increase in the width of the adrenal glands' zone fasiculata was observed in the descendants of group 3 (males and females were subjected to tobacco intoxication with "Priluki" light cigarettes) was by $15 \%$ and in group 6 it was by $13 \%$. Group 6 rat descendants had the medullary substance area increased twice. The obtained results indicate the hormones secretion activating in the respective adrenal glands areas, which is a sign of the descendant's stress in the mentioned experimental groups. In group 5 , reduction of the medullary substance area was by $24 \%$, which may be due to its function's depletion. Histological studies of the adrenal glands in the second group showed an increase of the spongiocytes nuclei, the cytolysis areas occurrence, and in animals of group 3, hyperplasia of spongiocytes was determined. In group 3 , the absolute thymus mass grew by $81 \%$, in group 6 it increased by $55 \%$. In these groups, the relative thymus mass grew by $50 \%$ in comparison with the control groups. In groups 3, 5, 6 the area of epithelial cells' nuclei grew (by $17 \%, 21 \%$ and $34 \%$, respectively).

Conclusions. The revealed changes are specific manifestations of the compensatory response to wounds healing in the descendants whose parents were subjected to chronic fumigation.

Keywords: local immunity, mechanical wound, passive tobacco smoking, adrenal glands, spongiocytes, thymus, epithelial cells.

Research relation to the department plans, programs and themes. The work is a fragment of the research project "Reactivity and resistance status of rats descendant born of tobacco intoxicated parents", state registration No. 01.15.U005819.

Introduction. In recent years, the effects of tobacco smoking on health have been studied almost comprehensively. Many clinical and experimental studies have proved the negative impact of tobacco smoke components on direct smokers, primarily on the respiratory and cardiovascular systems, causing chronic obstructive pulmonary disease and oncology diseases [3, 12, 15].

The study of passive smoking on human health is episodic and fragmentary, and the issues of the longterm parent tobacco-smoking consequences' effects on the child's development and health are revealed to a lesser degree. Thus, clinical studies [8, 17] showed that the fetal condition had pathological deviations under different smoking options in parents. In experimental work by Gubina-Vakulik, Yunusova, Lukyanova [7] it is stated that tobacco-smoking modeling in parent rats causes endothelial dysfunction of blood vessels in newborns, which is the most pronounced in the endothelium status changes of both genders in the case of the both parents "tobaccosmoking".

One of the most topical and poorly studied issues is the immune and endocrine systems status of 


\section{Біологічні науки}

children born in the parental smoking conditions. The latter is characterized during pregnancy as a chronic distress of varying severity [8]. According to modern ideas, the most important organs of the immuneendocrine system involved in reactions to stress are thymus and adrenal glands, whose action is aimed at supporting homeostasis. It is known that adrenal hormones (glucocorticoids) suppress cellular and humoral immunity, reduce the number of lymphocytes in the blood, thereby reducing the process of inflammation. On the other hand, thymus hormones play an important role in the adrenal function's regulation [9]. In experimental studies, it was found that glucocorticoids had a modeling effect on the epithelial cells of the thymus stroma and on the secretion of biologically active substances, as well as on the thymocytes differentiation and the T-cell receptors occurrence. According to Labunets, Magdych [9], in the immune endocrine interaction, thymus has a reversible effect on the neuroendocrine system and is important for the stress reaction implementation involving the epiphysis and adrenal glands. Thus, in adult animals after the thymus removal, the reaction of the epiphysis and the adrenal glands to stress is discontinued. This can partly be explained by the ability of the tymic hormone to directly inhance the melatonin secretion by the epithysis and that of corticosterone by the adrenal glands. In our previous experimental studies [13], it was found that tobacco intoxication of rat parents with "Vatra" "heavy" cigarettes without a filter led to disorders of resistance in their descendant during wounds healing, causes changes in the adrenal glands morphology [14].

The purpose of our research was to study the morphofunctional status of the adrenal glands and thymus in the descendant with a mechanical wound to determine the long-term consequences effects of their parents' passive smoking on resistance and reactivity.

Material and methods. The study was carried out on 73 rats (25 females and 10 males aged 3 months; 38 descendant females at the age of 2 months) belonging to the Vistar line. The animals were kept under normal vivarium conditions under natural light, with a common diet. The use of water was free.

Males and females were subjected to intoxication with tobacco smoke from "Priluki" light cigarettes containing $0.6 \mathrm{mg}$ of nicotine and $12 \mathrm{mg}$ of resin.

Modeling of chronic tobacco smoking was carried out using a specially designed 27 liters hermetic chamber. (Certificate of Acceptance No. 3991837 dated December 13, 1985, State Committee on Inventions and Discoveries.). Tobacco smoke of $1 / 2$ cigarettes was dosed into the chamber, while in the chamber there were simultaneously 5 animals during a
15 minutes period (5 minutes for the injection of smoke into the chamber and 10 minutes for the observation of animals' behavior). During the first 2-3 fumigations the animals were kept in a chamber for 10 minutes. The experiment lasted 5 months, the total of 51 fumigations were performed, and the control animals were kept for 15 minutes in the same chamber, but were not exposed to tobacco smoke. During the mating period, fumigation of experimental animals was not carried out. To study the resistance in the descendants born in the conditions of parental smoking, the morphofunctional status of the adrenal glands and thymus were studied in healing wounds. For this purpose, the infant rats of the studied groups, at the age of 2 months, were made cuts $10 \mathrm{~mm}$ long, $3 \mathrm{~mm}$ wide, on the outer surface of the right hind limb, within a single day.

According to the time schedule of the descendant's withdrawing from the experiment (sacrificing), which was carried out in $24 \mathrm{~h}$ and $48 \mathrm{~h}$ after the incision, the rats were divided into groups: 1, 4-the control group of descendants, who were sacrificed after mechanical wounding in $24 \mathrm{~h}$ and $48 \mathrm{~h}$, respectively; 2, 5 - the experimental groups of descendants, where only males was subjected to passive tobacco smoking, and the infant rats were sacrificed after mechanical wounding in $24 \mathrm{~h}$ and $48 \mathrm{~h}$, respectively; 3, 6 descendants obtained from the males and females that were both exposed to tobacco intoxication, sacrificed after mechanical wounding in $24 \mathrm{~h}$ and $48 \mathrm{~h}$, respectively.

To analyze the obtained data, the reference values of the studied indices in the intact animals were used, being obtained in the research at the DM habil. Professor Ya. R. Sinelnikov (Department of Anatomy and Physiology of Humans and Animals, Kharkiv H.S. Skovoroda National Pedagogical University).

To establish the degree of rats' intoxication with tobacco smoke, the amount of the main nicotine metabolite in serum - thiocyanide $\mathrm{K}$ (cotinine) was determined by the spectrophotometry method [1]. The ratsparents' blood serum study was carried out at the Laboratory of Biochemistry under the Central Research Laboratory of the Kharkiv National Medical University. Sacrificing of experimental animals was carried out in accordance with the euthanasia rules indicated in the instructional guidelines authorized by the $\mathrm{MOH}$ of Ukraine and with the general ethical principles of performing animal experiments, agreed with the provisions of the "European Convention for the Protection of Vertebrate Animals Used for Research and Other Scientific Purposes" [4]. Euthanasia of animals was carried out by intraperitoneal administration of a three-fold narcotic dose of sodium pentobarbital. 
After decapitation, the adrenal glands and thymus were taken from the descendant. The rats' body weight was controlled by weighing the animals with the VNC-2M (error: $\pm 2 \mathrm{~g}$ ) dial desktop scales. To determine the absolute mass of adrenal glands, the thymus was weighed with AXIS AN50 (fission price $0.0001 \mathrm{~g}$ ) analytical electronic scales. Subsequently, the relative mass of the adrenal glands and thymus was calculated, which was calculated in relation to the animal's body weight.

The adrenal glands and thymus were fixed in $10 \%$ neutral formalin, dehydrated in alcohols of ascending concentration, and embedded into paraffin blocks. Sections 5-6 $\mu \mathrm{m}$ thick were stained with hematoxylineosin. Light microscopy was performed using a Zeiss microscope (Germany). The morphometry of infant rats' adrenal glands and thymus was performed using a Biolam microscope (Russian Federation) with the magnification of $x 400$. Microscopy was performed with an "Olympus" microscope (Japan).

The adrenal glands morphofunctional activity was determined by counting the number of spongiocytes (cells of the adrenal glands' zona fasiculata) and computerized kariometry in digital images was performed using software suitable for the "Olympus" microscope (Japan); the medullary substance area and the width of the glomerular, fasiculata, reticularis zones were measured using the LOMO microscope with the AM29 ocular micrometer. In each specimen, 10 fields of view were assessed by means of random sampling. In the selected samples, 30 nuclei were studied. The thymus epithelial cells kariometry was performed using the similar procedure.

The differences reliability was assessed using the t-Student's test, with $P<0.01, P<0.05$. Digital material was processed according to the standard methods of variation statistics [10].

Results of the study and their discussion. In order to diagnose chronic tobacco intoxication in the parent rats' blood, the content of the main nicotine metabolite, cotinine, was determined $[2,5]$. The statis- tically significant growth of cotinine $(8.12 \pm 0.42 \mu \mathrm{g} / \mathrm{I}$, $\mathrm{P}<0.05)$ in animals subjected to fumigation with "Priluki" light cigarettes when compared to the control group $(6.34 \pm 0.32 \mu \mathrm{g} / \mathrm{I})$ is an irresistible proof to the fact of the passive tobacco intoxication.

It is known that manifestations of prolonged stresses, including tobacco smoking, are disorders of the immune and neuroendocrine systems, and the first signs of stress are morphofunctional changes of the adrenal glands and thymus [9]. Analyzing the obtained data, it was found that the absolute thymus mass in the descendant of group 4 grew twice as compared to the reference values, whereas in group 1 the thymus absolute weight did not change. Relative mass of the thymus in the specified groups remained at the level of reference values. In group 2, the absolute weight of the thymus grew by $41 \%$, in group 3 it increased by $81 \%\left(P^{* *}<0.01\right)$, in group 6 it grew by $55 \%\left(P^{* *}<0.01\right)$ in comparison with the control groups. In these groups the thymus relative mass increased by $50 \%\left(P^{*}<0.01, P^{* *}<0.01\right)$ in comparison to the reference values and the control groups (table 1).

The absolute mass of the adrenal glands did not have a statistically significant difference in the infant rats of the control and experimental groups compared to the reference values. However, in the descendant of group 4, the adrenal glands relative mass growth by $44 \%(P * \leq 0.01)$, and the tendency to reduce by $11 \%$ in group 1 compared to the reference values were observed (table 2).

The relative weight of the adrenal glands is significantly reduced in the descendant of group 2, where only males were fumigated, only compared to reference values, by $25 \%\left(P^{*}<0.01\right)$. In group 5 , the relative weight of the adrenal glands did not differ from the control and reference values. In the descendant of groups 3, 6 the relative weight of the adrenal glands is increased in comparison with the reference values, by $33 \%\left(\mathrm{P}^{*}<0.01\right)$ and by $61 \%\left(\mathrm{P}^{*}<0.01\right)$ respectively. It should be noted that the relative weight of the adrenal glands in group 3 compared to group 1 is increased

Table 1 - The thymus weight $(\mathrm{g})$, the relative thymus weight $(\mathrm{g} / \mathrm{g})$, and the nuclei area of epithelial cells $\left(\mu \mathrm{m}^{2}\right)$ of the descendant whose parents were subjected to the "Priluki" light cigarettes smoking

\begin{tabular}{l|c|c|c|c|c|c|c}
\hline \multicolumn{1}{c|}{ Indices } & $\begin{array}{c}\text { Reference } \\
\text { value }\end{array}$ & $\begin{array}{c}1 \\
(\mathrm{n} 5)\end{array}$ & $\begin{array}{c}2 \\
(\mathrm{n} 5)\end{array}$ & $\begin{array}{c}3 \\
(\mathrm{n} \mathrm{7})\end{array}$ & $\begin{array}{c}4 \\
(\mathrm{n} \mathrm{5})\end{array}$ & $\begin{array}{c}5 \\
(\mathrm{n} 6)\end{array}$ & $\begin{array}{c}6 \\
(\mathrm{n} \mathrm{10)}\end{array}$ \\
\hline $\begin{array}{l}\text { Thymus } \\
\text { weight, g }\end{array}$ & $0.11 \pm 0.01$ & $0.12 \pm 0.01$ & $\begin{array}{c}0.17 \pm 0.02 \\
\mathrm{P}^{*}<0.01 \\
\mathrm{P}^{* *}<0.01\end{array}$ & $\begin{array}{c}0.29 \pm 0.06 \\
\mathrm{P}^{*}<0.01 \\
\mathrm{P}^{* *}<0.01\end{array}$ & $\begin{array}{c}0.22 \pm 0.02 \\
\mathrm{P}^{*}<0.01\end{array}$ & $0.21 \pm 0.02$ & $\begin{array}{c}0.34 \pm 0.02 \\
\mathrm{P}^{*}<0.01 \\
\mathrm{P}^{* *}<0.01\end{array}$ \\
\hline $\begin{array}{l}\text { Relative } \\
\text { thymus } \\
\text { weight, g/g }\end{array}$ & $0.002 \pm 0.001$ & $0.002 \pm 0.001$ & $0.002 \pm 0.001$ & $\begin{array}{c}0.003 \pm 0.001 \\
\mathrm{P}^{*}<0.01 \\
\mathrm{P}^{* *}<0.01\end{array}$ & $0.002 \pm 0.001$ & $0.002 \pm 0.001$ & $\begin{array}{c}0.003 \pm 0.001 \\
\mathrm{P}^{*}<0.01 \\
\mathrm{P}^{* *}<0.01\end{array}$ \\
\hline $\begin{array}{l}\text { Nuclei area, } \\
\mu \mathrm{m}^{2}\end{array}$ & $11.73 \pm 0.22$ & $11.16 \pm 0.18$ & $11.13 \pm 0.49$ & $\begin{array}{c}13.03 \pm 0.58 \\
\mathrm{P}^{*}<0.01 \\
\mathrm{P}^{* *}<0.01\end{array}$ & $10.02 \pm 0.01$ & $\begin{array}{c}12.07 \pm 0.61 \\
\mathrm{P}^{*}<0.01 \\
\mathrm{P}^{* *}<0.01\end{array}$ & $\begin{array}{c}13.43 \pm 0.53, \\
\mathrm{P}^{*}<0.01 \\
\mathrm{P}^{* *}<0.01\end{array}$ \\
\hline
\end{tabular}

Note: $\mathrm{P}^{\star}<0.01$-compared to the reference values; $\mathrm{P}^{\star \star}<0.01-$ compared to the control groups. 


\section{Біологічні науки}

Table 2 - Weight $(\mathrm{g})$, relative weight $(\mathrm{g} / \mathrm{g})$, width of cortical zone $(\mu \mathrm{m})$ and the medullary substance area $\left(\mathrm{mm}^{2}\right)$ of adrenal glands in the descendant whose parents were subjected to fumigation with "Priluki" cigarettes

\begin{tabular}{|c|c|c|c|c|c|c|c|}
\hline Indices & $\begin{array}{l}\text { Reference } \\
\text { values }\end{array}$ & $\begin{array}{c}1 \\
(n 5)\end{array}$ & $\begin{array}{c}2 \\
(\mathrm{n} 5)\end{array}$ & $\begin{array}{c}3 \\
(n 7)\end{array}$ & $\begin{array}{c}4 \\
(n 5)\end{array}$ & $\begin{array}{c}5 \\
(n 6)\end{array}$ & $\begin{array}{c}6 \\
(n 10)\end{array}$ \\
\hline Weight $(\mathrm{g})$ & 001 & $0.001 \pm 0.001$ & $0.002 \pm 0.001$ & $0.002 \pm 0.001$ & $0.001 \pm 0.001$ & $0.002 \pm 0.001$ & $0.002 \pm 0.001$ \\
\hline $\begin{array}{l}\text { Relative } \\
\text { weight }(\mathrm{g} / \mathrm{g})\end{array}$ & $.0018 \pm 0.001$ & $0.0016 \pm 0.001$ & $0.0012 \pm 0.001$ & $\begin{array}{c}0.0024 \pm 0.001 \\
P^{*}<0.01 \\
P^{\star *}<0.01\end{array}$ & $\begin{array}{c}0.0026 \pm 0.001 \\
P^{*}<0.01\end{array}$ & $0.0020 \pm 0.001$ & $\begin{array}{c}0.0029 \pm 0.001 \\
P^{*}<0.01 \\
P^{* *}<0.01\end{array}$ \\
\hline $\begin{array}{l}\text { Zona glome- } \\
\text { rulosa, } \mu \mathrm{m}\end{array}$ & $63.53 \pm 3.42$ & $67.78 \pm 3.90$ & $\begin{array}{c}77.78 \pm 3.24 \\
\mathrm{P}^{*}<0.01 \\
\mathrm{P}^{\star *}<0.01 \\
\end{array}$ & $\begin{array}{c}77.94 \pm 3.98 \\
\mathrm{P}^{*}<0.01 \\
\mathrm{P}^{* *}<0.01 \\
\end{array}$ & $\mathrm{P}^{*}<$ & $\begin{array}{c}77.5 \pm 3.75 \\
\mathrm{P}^{*}<0,01 \\
\mathrm{P}^{\star *}<0.01\end{array}$ & $66.58 \pm 3.51$ \\
\hline $\begin{array}{l}\text { Zona fasicu- } \\
\text { lata, } \mu \mathrm{m}\end{array}$ & $70 \pm 17.2$ & $\begin{array}{c}353.44 \pm 13.19 \\
P^{*}<0.01 \\
P^{* *}<0.01\end{array}$ & $\begin{array}{c}262.27 \pm 12.16 \\
\mathrm{P}^{*}<0.01 \\
\mathrm{P}^{\star *}<0.01\end{array}$ & $\begin{array}{c}406.88 \pm 16.73 \\
P^{*}<0.01 \\
P^{* *}<0.01\end{array}$ & $362.19 \pm 12.46$ & $\begin{array}{c}239.5 \pm 11.04 \\
P^{*}<0.01\end{array}$ & $\begin{array}{c}411.58 \pm 20.46 \\
P^{*}<0.01 \\
P^{* *}<0.01\end{array}$ \\
\hline $\begin{array}{l}\text { Reticular } \\
\text { zone, } \mu \mathrm{m}\end{array}$ & 256.11 & $261.18 \pm 8.05$ & $\begin{array}{c}337.5 \pm 16.84 \\
P^{*}<0.01 \\
P^{* *}<0.01\end{array}$ & $\begin{array}{c}305.31 \pm 15.22 \\
\mathrm{P}^{\star}<0.01 \\
\mathrm{P}^{\star *}<0.01\end{array}$ & $\begin{array}{c}279.72 \pm 8.81 \\
P^{*}<0.01\end{array}$ & $282.0 \pm 14.67$ & $264.21 \pm 13.69$ \\
\hline $\begin{array}{l}\text { Medulary } \\
\text { substance, } \\
\mathrm{mm}^{2}\end{array}$ & $0.28 \pm 0.05$ & $0.25 \pm 0.07$ & $0.26 \pm 0.04$ & $\begin{array}{c}0.47 \pm 0.02 \\
P^{*}<0.01 \\
P^{* *}<0.01\end{array}$ & $0.29 \pm 0.01$ & $\begin{array}{c}0.22 \pm 0.07 \\
\mathrm{P}^{*}<0.01 \\
\mathrm{P}^{* *}<0.01\end{array}$ & $\begin{array}{c}0.63 \pm 0.03 \\
\mathrm{P}^{*}<0.01 \\
\mathrm{P}^{* *}<0.01\end{array}$ \\
\hline
\end{tabular}

Note: $\mathrm{P}^{*}<0.01$-compared to the reference values; $\mathrm{P}^{\star *}<0.01-$ compared to the control groups.

by $50 \%\left(P^{* \star}<0.01\right)$, and in group 6 does not have statistically significant difference (table 2). Meanwhile, in these groups, the relative weight of the thymus is also increased in comparison with the reference values and with those in the control groups $(1,4)$ (table 1).

In the process of the thymus cells (thymocytes) maturation, an important role is played by epithelial cells. In groups 3, 5, 6 in comparison with groups 1 and 4 , the epithelial cell nuclei area has grown by $21 \%, 17 \%$ and $34 \%$ respectively $\left(P^{* *}<0.01\right)$. Similar changes were also observed when comparing the nuclei area of epithelial cells in infant rats with the reference data $\left(P^{*}<0.01\right)$. In the descendant of group 2 , statistically significant changes in the morphofunctional structure of the thymus compared to those in the control group 1 have not been established (table 1).

Smoking of parents and wounding of their descendants can be considered a condition that requires adaptation changes, in which the adrenal glands play an essential role. The histological structure of the adrenal glands is significantly different from the control ones in the experimental groups of infant rats. In the descendants of groups 2, 3 and 5 the width of the glomerular zone has statistically significantly increased both in the control groups and in the reference values. The glomerular area growth in the adrenal glands was also observed in the descendants whose mothers were subjected to hypoxia [15]. In group 6, this index was almost unchanged compared to the reference values and the control group's indices (table 2).

The width of the zona fasiculata in groups where passive smoking was restricted to males was reduced by $25 \%$ in group $2\left(\mathrm{P}^{* *}<0.01\right)$, and in group 5 by $34 \%$ $\left(P^{* *}<0.01\right)$ in comparison with the control groups. In the descendants of the groups where mothers and fathers (groups 3,6) were subjected to passive smoking, the opposite changes occurred: the width of the zona fasiculata in their adrenal glands increased by $15 \%\left(P^{* *}<0.01\right)$ and $13 \%\left(P^{* *}<0.01\right)$ (table 2), in comparison with the control values. Similar changes were observed when comparing the above indices of adrenal glands to the reference values. In the zona fasiculata of the control group we found no cytolysis foci observed in groups 2, 5 (fig. 1, fig. 2, respectively).

Glucocorticoids play an important role in wound healing. Therefore, in the adrenal glands' zona fasiculata, the spongiocytes number counting was carried out, where the main glucocorticoids synthesis took place (in rats it is corticosterone). In groups 2 and 5, the number of spongiocytes reduced statistically

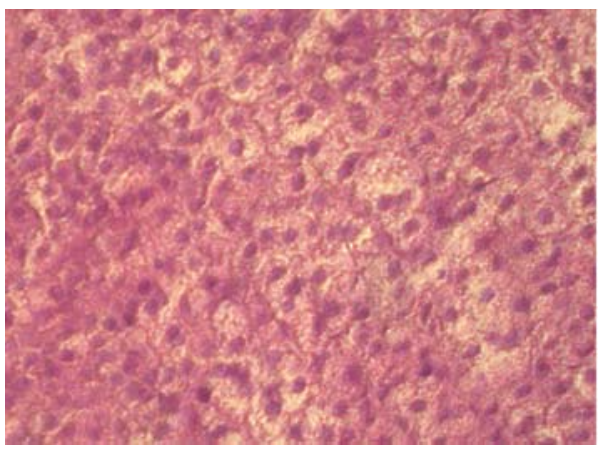

Fig. 1. Zona fasiculata of the adrenal glands cortex in the animals of group K24. Spongiocytes have a dark, rounded nucleus and varying degrees of vacuolated cytoplasm.

Staining with hematoxylin-eosin. Magnification x 400 


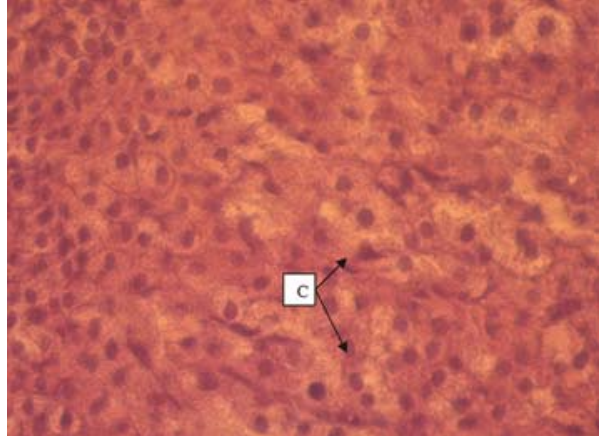

Fig. 2. Zona fasiculata of the adrenal glands cortex in the animals of group 2. Enlargement of spongiocytes nuclei, occurrence of cytolysis foci (C). Staining with hematoxylineosin. Magnification x 400

significantly by $27 \%\left(\mathrm{P}^{* *}<0.01\right)$ and $25 \%\left(\mathrm{P}^{* *}<0.01\right)$, respectively, in comparison to groups $\mathrm{K} 24, \mathrm{~K} 48$. Such changes were also observed when comparing this index with the reference values (table 3).

The descendants in the groups where only males were subjected to passive smoking, had an increased nuclei area and a reduced number of spongiocytes (table 3), thus indicating the increased morphofunctional activity of the adrenal glands. In future, such changes can lead to an accelerated exhaustion of their functioning. Our data is to some extent consistent with Skurchak's study [11], which shows a decrease of the spongiocytes' diameter and the cellular elements' density in stillbirths from mothers who suffered from alcoholism and drug addiction.

The revealed spongiocytes hyperplasia of the adrenal glands zona faciculata in group 3 descendants (mother and father were subjected to fumigation) (table 3, fig. 3) is a manifestation of compensatory and adaptive reactions in response to chronic tobacco intoxication of parents.

In the zona fasiculata of group 6, there are no signs of hyperplasia, which is confirmed by an equal number of cells with the control group and the reference values. The width of the reticular zone grew in groups 2 by $29 \%\left(P^{* *}<0.01\right)$ and in group 3 by $16 \%$ $\left(P^{* *}<0.01\right)$, while in groups 5 and 6 this index did not have a statistically significant difference compared to the control and reference values.

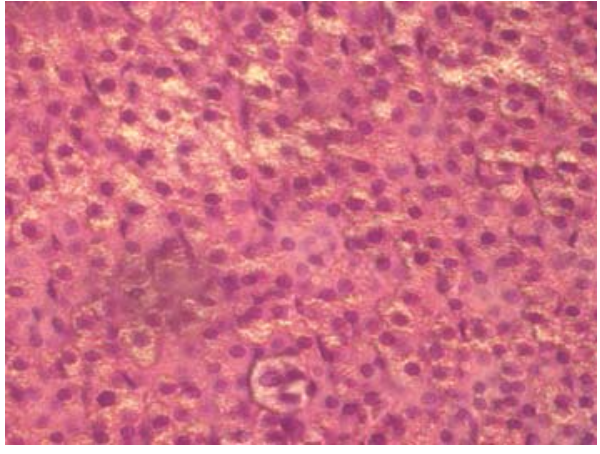

Fig. 3. Zona fasiculata of the adrenal glands cortex in the animals of group 3. Hyperplasia of spongy sac. Staining with hematoxylin-eosin. Magnification x 400

The medullary substance area in the descendant of the groups, where the male and female $[3,6]$ were subjected to fumigation, grew up $\left(P^{\star *}<0.01, P^{*}<0.01\right)$, which is pathognomonic of the adaptive reaction development. It should be noted that in group 6 the medullary substance area grows by 2 times compared to the reference values as well as in group 4. However, in group 5 , the reduction of the medullary substance area by $24 \%\left(P^{* *}<0.01\right)$, compared to group 4 and the reference values $\left(P^{*}<0.01\right)$, indicates the depletion of these glands function (table 2). The obtained morphohistological changes in the adrenal glands of the infant rats in experimental groups are consistent with the data of other authors and are consequences of compensatory and adaptive reactions in the descendant under the effect of hypoxia, which occurs when parents are smoking tobacco [16].

Summarizing the above, it can be stated that more pronounced changes in the organs of the immune endocrine system (thymus and adrenal glands), are observed in the mechanically wounded descendant, obtained from rat parents who were subject to passive smoking (groups 3,6 ). In this descendant, the relative weight of the thymus increases on the background of an increase in the adrenal glands relative weight. The increase in the adrenal glands relative weight, as well as the detected changes in the morphofunctional status of these glands, indicate that this wounded descendant was more sensitive to parental

Table 3 - Number of spongiocytes $\left(S=928 \mu \mathrm{m}^{2}\right)$ and their kariometric indices $\left(\mu \mathrm{m}^{2}\right)$ of the adrenal glands zona fasiculata in the descendant whose parents were subjected to fumigation with "Priluki" light cigarettes

\begin{tabular}{l|c|c|c|c|c|c|c}
\hline \multicolumn{1}{c|}{ Indices } & $\begin{array}{c}\text { Reference } \\
\text { values }\end{array}$ & $\begin{array}{c}1 \\
(\mathrm{n} 5)\end{array}$ & $\begin{array}{c}2 \\
(\mathrm{n} 5)\end{array}$ & $\begin{array}{c}3 \\
(\mathrm{n} 7)\end{array}$ & $\begin{array}{c}4 \\
(\mathrm{n} 5)\end{array}$ & $\begin{array}{c}5 \\
(\mathrm{n} 6)\end{array}$ & $\begin{array}{c}6 \\
(\mathrm{n} 10)\end{array}$ \\
\hline $\begin{array}{l}\text { Number of } \\
\text { spongiocytes, } \\
\text { units }\end{array}$ & $19.18 \pm 0.89$ & $19.22 \pm 0.86$ & $\begin{array}{c}13.89 \pm 0.77 \\
\mathrm{P}^{*}<0.01 \\
\mathrm{P}^{* *}<0.01\end{array}$ & $\begin{array}{c}22.56 \pm 1.26 \\
\mathrm{P}^{*}<0.01 \\
\mathrm{P}^{* *}<0.01\end{array}$ & $18.56 \pm 0.73$ & $\begin{array}{c}14.3 \pm 0.52 \\
\mathrm{P}^{*}<0.01 \\
\mathrm{P}^{* *}<0.01\end{array}$ & $19.1 \pm 0.71$ \\
\hline $\begin{array}{l}\text { Nuclei area, } \\
\mu \mathrm{m}^{2}\end{array}$ & $16.87 \pm 0.54$ & $17.04 \pm 0.74$ & $\begin{array}{c}20.56 \pm 0.63 \\
\mathrm{P}^{*}<0.01 \\
\mathrm{P}^{* *}<0.01\end{array}$ & $17.58 \pm 0.50$ & $17.39 \pm 0.59$ & $\begin{array}{c}19.98 \pm 0.76 \\
\mathrm{P}^{*}<0.01 \\
\mathrm{P}^{* *}<0.01\end{array}$ & $16.78 \pm 0.62$ \\
\hline
\end{tabular}

Note: $\mathrm{P}^{*}<0.01$-compared to the reference values; $\mathrm{P}^{\star *}<0.01-$ compared to the control groups. 


\section{Біологічні науки}

smoking. However, the involutional processes in the thymus were not detected, which was confirmed by the relative weight increase of the organ. The increase in the experimental animals' thymus weight in animals subjected to stress is also evidenced by the studies of Gorodetsky, Korenevskaya [8]. However, according to Zeyrek, Ozturk, Ozturk, and Carmak studies, maternal smoking substantially affects the reduction of thymus weight in the descendants [18].

Thus, changes in the relative weight of the adrenal glands, thymus and changes in the morphofunctional status of these glands in the infant rats can indirectly characterize the overall adaptive reaction of the organism depending on the fumigation of the only parent, or the both father and mother, as well as on the period of the skin cut performed. An increase in the thymus relative weight and an increase in the epitheliocytes nuclei area in groups 3 and 6 causes specific manifestations of the stress response to wound healing in the descendant whose parents were subjected to chronic fumigation.

Reducing of the spongiocytes total number in the descendant of groups 2 and 5 is a sign of decompensation, primarily in the adrenal cortex zona fasiculata. Significant increase in the width of the adrenal glands zona fasiculata in the descendants of groups 3, 6 with multiplied hypoxic action, which develops under the influence of tobacco smoke, indicates the involvement of this zone's hormones (primarily glucocorticoids) into the general adaptive syndrome implementation. The increase in the medulla substance area, where the adrenalin is secreted, in the infant rats of groups 3, 6 testifies to the stress exposure of the experimental groups animals, and its reduction in group 5 proves the exhaustion of the medulla substance's function.

\section{Conclusions}

1. Experimental models of passive smoking and mechanical wounding were used to detect changes in the morphohistological parameters of the thymus and adrenal glands in experimental animals, depending on fumigation of the a father only, or both parents, and also on the period of the skin cut performed.

2. The most significant changes in the morphohistological structure of the thymus (an increase in the organ's absolute and relative weight, an increase in the epithelial cells nuclei area) occurred in the descendants, where both parents were subjected to passive smoking (groups 3,6 ).

3. The study showed that passive smoking of parents causes characteristic adaptive changes of the adrenal glands in their infant rats: hyperplasia of the cortex zona fasiculata (groups 3,6 ), reduction of spongiocytes proliferation, which led to their increased functional activity as a compensatory reaction (groups 2, 5).

Prospects for further research. In the future, a deeper study of the long-term effects of parental smoking on the reactivity and residency of their descendants is planned.

\section{References}

1. Belyayev SG, Gorbach TV. Modifitsirovannyy sposob opredeleniya tiotsianidnykh ionov v slyune i moche. Problemy suchasnoyi medychnoyi nauky ta osvity. 2009; 1: 88-90. [Russian]

2. Benowitz NL, Hukkanen J, Jacob P3rd. Nicotine chemistry, metabolism, kinetics and biomarkers. Handb Exp Pharmacol. 2009. 192, P. 29-60. doi: 10.1007/978-3-540-69248-5_2

3. Dolhosh MYu. Vyyavlennya faktoriv ryzyku sertsevo-sudynnykh zakhvoryuvan' u pratsivnykiv zaliznychnoho transportu. Naukovyy visnyk Uzhhorods'koho universytetu. Seriya «Medytsyna». 2011; 40: 32-6. [Ukrainian]

4. Eriksson M, Kaerlev L, Johansen P, Afonso N, Ahrens W, Costa-Pereira A, et al. Cancer Epidemiol. Tobacco smoking and alcohol consumption as risk factors for thymoma - A European case-control study. Cancer Epidemiol. 2019 Aug; 61: 133-8. PMID: 31254794. DOI: 10.1016/j.canep.2019.06.008

5. Evropeys'ka konventsiya pro zakhyst khrebetnykh tvaryn, shcho vykorystovuyut'sya dlya doslidnykh ta inshykh naukovykh tsiley. Strasburh, 18 bereznya1986 roku: ofitsiynyy pereklad [digital resource]. Verkhovna Rada Ukrayiny. Mizhnarodnyy dokument Rady Yevropy. [Ukrainian]Available from: https://zakon.rada.gov.ua/laws?lang=en

6. Goniewicz ML, Eisner MD, Lazcano-Ponce E, Zielinska-Danch W, Koszowski B, Sobczak A, et al. Comparison of urine cotinine and the tobacco-specifi c nitrosamine metabolite 4-(methylnitrosamino)-1-(3-pyridyl)-1-butanol (NNAL) and their ratio to discriminate active from passive smoking. Nicotine Tob Res. 2011; 13(3): 202-8. PMID: 21330276. PMCID: PMC3045466. DOI: 10.1093/ntr/ntq237

7. Gubina-Vakulik GÍ, Yunusov VYu., Luk'yanova YeM. Osobennosti razvitiya aorty i sosudov mikrotsirkulyatornogo rusla u novorozhdennykh potomkov roditeley-kuril'shchikov. Eksperymental'na i klinichna medytsyna. 2014; 3: 56-60. [Russian]

8. Horodetskaya YV, Korenevskaya NA. Vlyyanye tyreoydnoho statusa na yntensyvnost' stress-reaktsyy pry khronycheskom stressovom vozdeystvyy. Vestnyk Vitebskoho derzhavnoho medychnoho universytetu. 2010; 9(4): 24-33. [Russian]

9. Labunets' IF, Mahdych LV. Vikovi osoblyvosti imunoendokrynnoyi vzayemodiyi pry vplyvakh stresovykh chynnykiv. Problemy starinnya i dovholittya. 2012; 21(4): 444-55. [Ukrainian]

10. Lakin GF. Biometriya. M: Vysshaya shkola; 1990. 348 p. [Russian] 
11. Skurchak TN, Litvinenko MV, Sherstyuk SA, Buryachkovs'kiy YeS. Patomorfologiya pecheni mertvorozhdennykh ot $\mathrm{VICH}$-infitsirovannykh materey s sindromom zavisimosti ot alkogolya i narkoticheskikh veshchestv. Eksperymental'na $i$ klinichna medytsyna. 2015; 4: 32-5. [Russian]

12. Slepchenko NC. Palinnya ta kardiopul'monal'na patolohiya: vplyv na vynyknennya, perebih ta prohnoz. Visnyk Vinnyts'koho natsional'noho medychnoho universytetu. 2013; 1(17): 29-32. [Ukrainian]

13. Tkachenko VM, Komisova TYe. Stan mekhanichnoyi rany nashchadkiv, bat'ky yakykh pidlyahaly khronichniy tyutyunoviy intoksykatsiyi. Biolohiya ta valeolohiya. Zbirnyk naukovykh prats' Kharkivs'koho natsional'noho pedahohichnoho universytetu imeni HS Skovorody. 2015; 17: 90-4. [Ukrainian]

14. Tkachenko VM, Komisova TYe. Morfofunktsional'nyy stan nadnyrkovykh zaloz nashchadkiv-shchuriv, vynoshenykh $v$ umovakh bat'kivs'koho palinnya, yakym bula nanesena mekhanichna rana. Biolohiya ta valeolohiya. Zbirnyk naukovykh prats' Kharkivs'koho natsional'noho pedahohichnoho universytetu imeni HS Skovorody. 2016; 18: 82-91. [Ukrainian]

15. Tsuji H, Fujimoto H, Lee KM, Renne R, Iwanaga A, Okubo C, et al. Characterization of biochemical, functional and structural changes in mice respiratory organs chronically exposed to cigarette smoke. Inhal Toxicol. 2015; 27(7): 34253. doi: 10.3109/08958378.2015.1051248

16. Tovazhnyanskaya VD, Sorokina IV, Yakovtsova II. Morfo-funktsional'nyye osobennosti kory nadpochechnikov plodov krysy pri vozdeystvii khronicheskoy vnutriutrobnoy gipoksii. Aktual'ni problemy suchasnoyi medytsyny: Visnyk ukrayins'koyi medychnoyi stomatolohichnoyi akademiyi. 2015; 15(3/51): 259-63. [Russian]

17. Qu W, Zhao WH, Wen X, Yan HY, Liu HX, Hou LF, et al. Prenatal nicotine exposure induces thymic hypoplasia in mice offspring from neonatal to adulthood. Toxicol Lett. 2019 Apr; 304: 30-8. PMID: 30605750. DOI: 10.1016/ j.toxlet.2018.12.015

18. Zeyrek D, Ozturk E, Ozturk A, Carmak A. Pescreased thymus size in full-term newborn infahtsof smoking mothers. Med Sci Monit. 2008. Aug; 14/8.

\section{УДК 616-001.3-092.9-02:613.84}

\section{ВІДДАЛЕНІ НАСЛІДКИ ПАСИВНОГО КУРІННЯ БАТЬКІВ НА МОРФОФУНКЦІОНАЛЬНИЙ СТАН НАДНИРНИКІВ І ТИМУСА У ЇХНІХ НАЩАДКІВ \\ Ткаченко В. М., Комісова Т. Є.}

Резюме. В експерименті показано, що зміни в морфоффункціональному стані наднирників і тимуса у нащадків-щурів, виношених в умовах батьківського куріння, проявляються в залежності від обкурювання лише батька, або батька і матері, а також від термінів зробленого надрізу шкіри. Виявлено зменшення загальної кількості спонгіоцітов у нащадків виведених з експерименту на 24 год і 48 год після нанесення механічної рани, батька яких було піддано пасивному палінню сигаретами «Прилуки» легкі $(г р у п и ~ 2,5)$, відповідно на 27\% і на 25\%. Збільшення ширини пучкової зони наднирників відзначали у нащадків групи 3 (батько-самець і мати-самка піддавалися нікотиновій інтоксикації сигаретами «Прилуки» легкі), на 15\% і групи 6 - на 13\%. Також у щуренят групи 6 реєстрували збільшення площі мозкової речовини в два рази. Отримані дані свідчать про активізацію секреції гормонів відповідних зон наднирників, що є ознакою спресованості нащадків даних експериментальних груп. У групі 5 відзначається зменшення площі мозкової речовини на 24\%, що можливо пов'язано з виснаженням її функції. Гістологічними дослідженнями наднирників у нащадків групи 2 встановлено збільшення ядер спонгіоцитів, поява ділянок цитолізу, а у тварин групи 3 - гіперплазію спонгіоцітов. У групі 3 абсолютна маса тимусу збільшується на 81\%, в групі 6 - на 55\%. У цих групах збільшується на 50\% і відносна маса тимуса в порівнянні з групами 1, 4. У групах 3, 5, 6 збільшується площа ядер епітеліоцитів (на 17\%, 21\%, 34\%). Виявлені зміни є специфічними проявами компенсаторної відповіді на загоєння ран у нащадків, батьки яких зазнавали хронічного обкурювання.

Ключові слова: місцевий імунітет, механічна рана, пасивне куріння, наднирники, спонгіоціти, тимус, епітеліоцити.

УДК 616-001.3-092.9-02:613.84

\section{ОТДАЛЕННЫЕ ПОСЛЕДСТВИЯ ПАССИВНОГО КУРЕНИЯ РОДИТЕЛЕЙ НА МОРФОФУНКЦИОНАЛЬНОЕ СОСТОЯНИЕ НАДНОЧЕЧНИКОВ И ТИМУСА В ИХ ПОТОМКОВ}

Ткаченко В. Н., Комисова Т. Е.

Резюме. В эксперименте показано, что изменения в морфофункциональном состоянии надпочечников и тимуса у потомков-крыс, выношенных в условиях родительского курения, проявляются в зависимости от обкуривания только отца, или отца и матери, а также от сроков сделанного надреза кожи. Выявлено уменьшение общего количества спонгиоцитов у потомков выведеных из эксперимента на 24 ч и 48 ч 


\section{Біологічні науки}

после нанесения механической раны, отцы которых подвергались пасивному курению сигаретами «Прилуки» легкие (группы 2, 5), соответственно на 27\% и на 25\%. Увеличение ширины пучковой зоны надпочечников отмечали у потомков группы 3 (отец-самец и мать-самка подвергались никотиновой интоксикации сигаретами «Прилуки» легкие), на 15\% и группы 6 - на 13\%. Также у крысят группы 6 регистрировали увеличение площади мозгового вещества в два раза. Полученные данные свидетельствуют об активизации секреции гормонов соответствующих зон надпочечников, что является признаком стрессированности потомков данных экспериментальных групп. В группе 5 отмечается уменьшение площади мозгового вещества на 24\%, которое возможно связано с истощением ее функции. Гистологическими исследованиями надпочечников потомков группы 2 установлено увеличение ядер спонгиоцитов, появление участков цитолиза, а у животных группы 3 - гиперплазию спонгиоцитов. В группе 3 абсолютная масса тимуса увеличивается на $81 \%$, в группе 6 - на 55\%. В этих группах увеличивается на $50 \%$ и относительная масса тимуса в сравнении с группами 1, 4. В группах 3, 5, 6 увеличивается площадь ядер эпителиоцитов (соответстенно на 17\%, 21\%, 34\%). Выявленные изменения являются специфическими проявлениями компенсаторного ответа на заживление ран у потомков, родители которых подвергались хроническому обкуриванию.

Ключевые слова: местный иммунитет, механическая рана, пассивное курение, надпочечники, спонгиоциты, тимус, эпителиоциты.

The authors of this study confirm that the research and publication of the results were not associated with any conflicts regarding commercial or financial relations, relations with organizations and/or individuals who may have been related to the study, and interrelations of coauthors of the article.

Стаття надійшла 07.06.2019 р. Рекомендована до друку на засіданні редакційної колеаії після рецензування 